\title{
REVIIITING THE IMPACTS OF THE ECONOMIC CRISES ON ACHIEVING THE MDG 4
}

REVISANDO LOS IMPACTOS DE LAS CRISIS ECONÓMICAS PARA LOGRAR EL ODM 4

M. Carmen Blanco-Arana Universidad de Málaga c.blancoarana@uma.es

Recibido: marzo de 2018; aceptado: febrero de 2018

\section{ABSTRACT}

Well into the XXI century, child mortality is still high in developing countries. The Millennium Declaration approved at the United Nations Millennium Summit held in September 2000 set down, as its fourth objective, the reduction of child mortality by two thirds; from the 93 children per 1,000 that died before the age of 5 in 1990, to 42 per 1,000 in 2015. To this end, considerable advances have been made although the proposed goal is still a long way off in some countries and regions.

In this context, the financial crisis of 2007-08 has, in addition, posed a serious threat to attaining this objective. In general terms, the recessionary phases of such cycles negatively impact the progress and welfare of countries with economic, political and social consequences for the population in general, and particularly for children.

Therefore, the principal objective of this paper is to revisit the main impact of the last global economic decline on the more vulnerable children of countries of the South, with a special focus on the goal proposed by the fourth Millennium Development Goal (MDG), given that it presently constitutes a great challenge for the whole population within the framework of the Sustainable Development Goals (SDGs).

Keywords: Economic crisis; the Great Recession; Child mortality; MDG; SDG. 
RESUMEN

En pleno siglo XXI la mortalidad infantil sigue siendo elevada en los países en desarrollo. La Declaración del Milenio aprobada en la Cumbre del Milenio de las Naciones Unidas celebrada en septiembre de 2000 marcó como cuarto objetivo la reducción de la mortalidad infantil en dos terceras partes, de los 93 niños por cada 1000 que morían antes de cumplir cinco años en 1990, a 42 por cada 1000 en 2015. En esta línea, se han conseguido avances considerables, aunque la meta propuesta ha quedado lejos de alcanzarse en algunos países y regiones.

En este contexto, la crisis financiera de 2007-08 ha suscitado, además, una notable amenaza para su consecuciōn. En términos generales, las fases recesivas de los ciclos afectan negativamente al progreso y bienestar de los paîses, con consecuencias económicas, políticas y sociales para la poblaciōn en general, y en particular, para los colectivos más vulnerables, como la infancia.

Por tanto, el principal objetivo de este trabajo es, poner de manifiesto los principales impactos del último deterioro económico global sobre la infancia más vulnerable de los países del Sur, prestando especial atención en lo que respecta a la meta propuesta por el cuarto Objetivo de Desarrollo del Milenio (ODM), ya que constituye actualmente un gran reto para toda la población dentro del marco de los Objetivos de Desarrollo Sostenibles (ODS).

Palabras clave: Crisis económica; la Gran Recesión; Mortalidad infantil; ODM; ODS.

JEL Classification: O10, O50, G01.

Acknowledgements. The author gratefully thanks Dr. Salvador Pérez-Moreno for his useful comments which have contributed to enriching the quality of this paper. 


\section{INTRODUCTION}

It is well known that economic cycles are intrinsic to the functioning of the economic system itself. These cycles affect the evolution of the economy as a whole, with economic, political and social consequences. Doubtless the situation of economic decline experienced in recent years has also caused a serious setback for the already impoverished economies of countries of the South, with the ensuing impact on the quality of life of their populations, particularly among the more vulnerable sectors, among which we find children. In this regard, we may expect that the advances achieved in favour of children over recent decades have vanished in some developing countries, thus decelerating even more the pace of reduction in child mortality in global terms.

More broadly, it seems clear that developing countries are particularly vulnerable in periods of economic crisis. According to Harper et al. (2009), in such situations increases may occur in child mortality and morbidity, child labour, child exploitation, violence against children and other forms of abuse, together with a decline in school attendance and the quality of education, as well as emotional well-being and child care. In this regard, Elson (2010) emphasizes in particular that the loss of income in many poor households can affect children in the form of malnutrition.

In addition to briefly highlighting the progress made in the area of children, especially child survival since the adoption of the Convention on the Rights of the Child in 1989, this paper aims to examine through the specific literature the main impacts of the last global economic deterioration on the most vulnerable children in the countries of the South, while paying particular attention to the achievement of the fourth MDG with the proposed target for 2015.

Thus, the present paper offers a review of the literature at international level concerning the links between the economic crises and the evolution of child mortality in the last decades, examining in the specialized literature both the analytical framework and the primary factors influencing the extent of the effects of the crisis on the most underprivileged children, with special emphasis on the main empirical global results of effects of the "Great Recession" on the evolution of child mortality rates in developing countries.

The remainder of the paper is as follows. Section 2 reviews the progress of children since the adoption of the Convention on the Rights of the Child. Section 3 revisits the impacts of economic crises on childhood. Section 4 revises the impact of the "Great Recession" on childhood in developing countries. The final section shows some final remarks. 
2. Progress of Children since the Adoption of the Convention on the Rights OF THE CHILD

On November 20, 1989, the Convention on the Rights of the Child was adopted by the General Assembly of the United Nations, an International Treaty which is the first legally-binding international law on the rights of children for the signatory countries. World leaders decided that children should have a special Convention dedicated exclusively to them. Since its inception the Convention has been the most ratified human rights treaty in the world. To be specific, it has been ratified by 193 countries (2010). All but two of the member nations of the United Nations (192) have ratified it, as have two nonUnited Nations countries (Niue and Cook Islands) and the Holy See.

The Convention on the Rights of the Child is the first legally binding international instrument incorporating the full range of human rights: civil, cultural, economic, political and social. It reflects the different situations in which children and young people from all over the world can find themselves.

Since the adoption of the Convention more than 25 years ago, considerable advances have been made in safeguarding the rights of the child in the areas of survival, development, protection and participation. However, much remains to be done to create a world fit for children, and in recent years the global economic crisis has threatened the continuity of these developments.

The latest estimates of child mortality recently published by the United Nations Inter-Agency Group for Child Mortality Estimation in 2018 show that the worldwide under-five mortality rate has dropped by more than a third, from 93 deaths per 1,000 live births in 1990 to 42 in 2015. Despite this notable decline, around 15,000 children under the age of five in the world are still dying every day for reasons that can be prevented $(70 \%$ of these deaths occur during the first year of life). Despite this reduction of more than a third between 1990 and 2015, the pace has not been sufficient in some countries of the South to achieve MDG 4 (to reduce by two thirds the deaths of children under five years of age between 1990 and 2015), which is currently a major challenge for the entire population within the framework of SDGs.

In the developing world, the level of child mortality is related to the socioeconomic level of a geographic area, with some countries showing significantly higher child mortality rates than others (see Figure 1, by regions). In this context, under-five mortality rates have declined considerably since 1990, falling by 54 percent, from 93 deaths per 1,000 live births in 1990 to 42 in 2015; although in some regions, such as sub-Saharan Africa, progress has been slower. 
Figure 1. Under-Five Mortality Rates

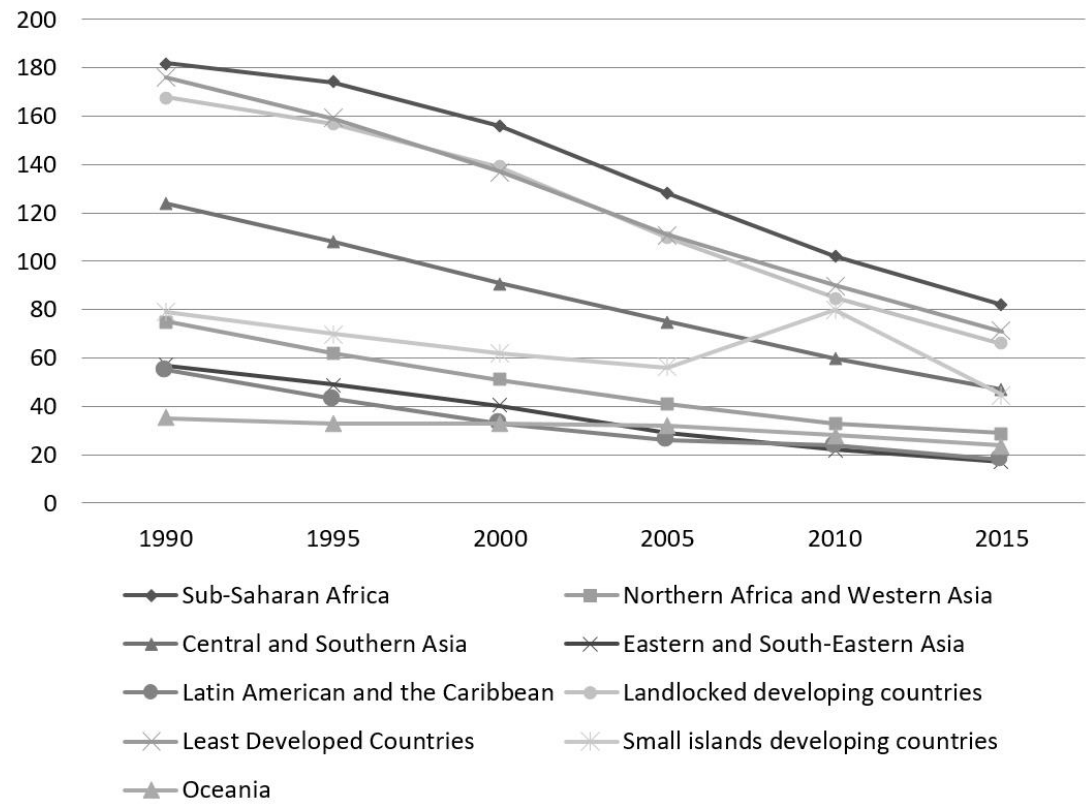

Source: United Nations Inter-Agency Group for Child Mortality Estimation (2018).

In this respect, only 2 of the 7 regions studied in Table 1 have achieved the goal set by MDG 4, which globally is clearly insufficient. This indicator refers to the survival of children, although it also reflects the social, economic and environmental conditions in which children live (Cuenca and Rodríguez, 2010).

\section{Impacts of Economic Crises on Childhood: Previous Experiences}

Economic history shows us that economic cycles, with stages of economic expansions and recessions, constitute an inevitable reality in the economic system. Periods of prosperity and hardship follow each other, with very adverse effects on the living conditions of the population in recessionary phases. The Great Depression that began in 1929, the Oil Crisis of 1973 and 1979, the subsequent recession of the first half of the 1980s -especially virulent for developing countries- or the Asian Crisis that emerged in 1997 are some of the examples we found throughout the twentieth century, with serious effects in all cases on the population in general and, especially, on childhood.

Let us focus on the crisis of the early eighties, which meant that many countries had to face a severe recession and growing economic imbalances, 


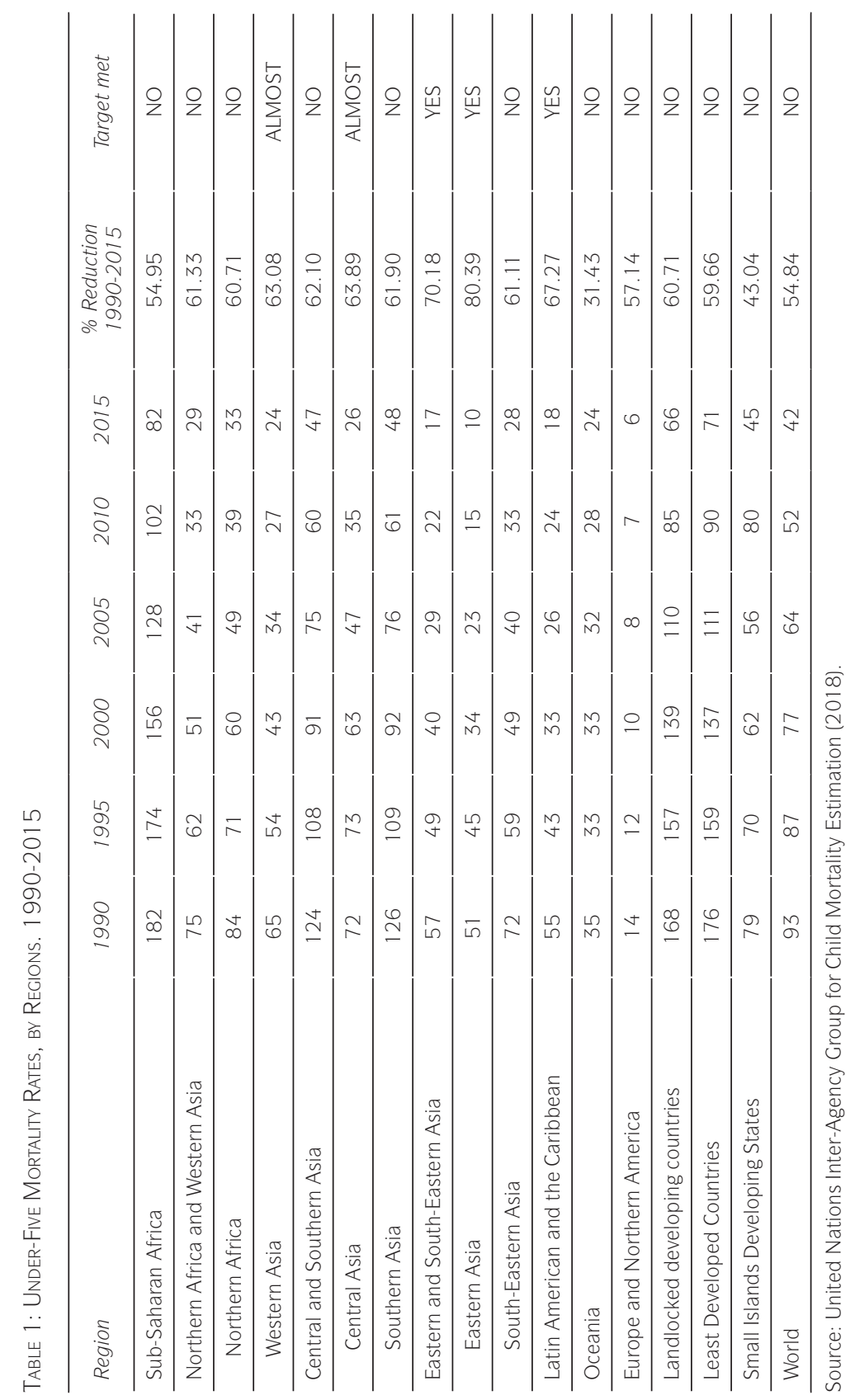


especially in their external accounts, while being forced to adopt policies of stabilization and adjustment of a restrictive nature, imposed mainly by international organizations.

Thus, after more than thirty years of sustained progress, the welfare of children experienced a serious deterioration during the first half of the 1980s. Faced with this situation, UNICEF promoted several investigations on the consequences of the global economic crisis on the most vulnerable groups. A result of these investigations was the publication of "Effects of the Global Recession on Childhood" (Jolly and Cornia, 1984), that preceded the most important study published in 1987 under the title of "Adjustment with a Human Face" (Cornia, Jolly and Stewart, 1987), which was the most elaborate alternative to the political recommendations advocated by the International Monetary Fund (IMF) and The World Bank since the seventies. This document defended the need for economic stabilization (orthodox adjustment, advocated by the IMF) and structural adjustment (growth-oriented adjustment, advocated by the World Bank); but it went further, defending that this adjustment should be made while guaranteeing the protection of vulnerable groups, so that the entire population had their basic needs covered for nutrition, health and education.

Therefore, there is no doubt then, that in the last decades child mortality and its connection with the economic cycle has aroused a high interest among academics and development professionals (see, for example, Ferreira and Schady, 2009; Bhalotra, 2010; Fernández and López-Calva, 2010; Schady and Smitz, 2010; Anderson et al., 2011; Renton et al., 2012; Pérez-Moreno et al., 2016, among others).

In relation to developing countries, we find first of all some country-specific studies that take into account the impacts of the economic recession on infant mortality and morbidity. From the group of works referring to Latin America we can mention: Cutler et al. (2002) on Mexico; Costa et al. (2003) on Brazil; Paxson and Schady (2005); and Miller and Urdinola (2010) on Colombia. Others focus on Asia, including: Rukumnuaykit (2003), and Block et al. (2004) on Indonesia; Lin (2006) on Taiwan; and Bhalotra (2010) on India. In reference to Africa we find: Yamano et al. (2005) on Ethiopia.

In the case of middle-income countries in Latin America, the evidence for the effect of economic recessions on infant mortality and morbidity is ambiguous. Cutler et al. (2002) observe in Mexico an increase in the child mortality rate of 0.06 percent compared to the period prior to the 1995-1996 crisis. Likewise, the deep economic crisis suffered in Peru in the late 1980s led to an increase of 2.5 percentage points in the infant mortality rate (Paxson and Schady, 2005). On the contrary, in Brazil there is a sustained decrease in child mortality in recessionary economic scenarios (Costa et al., 2003), as well as in rural areas of Colombia, where child survival improves during economic recessions (Miller and Urdinola, 2010).

Greater homogeneity is seen in Asian countries. On the one hand, the analysis of the financial crisis beginning in 1997 in Indonesia by Rukumnuaykit 
(2003) shows that the crisis has had adverse effects on neonatal mortality in urban and rural areas. Block et al. (2004) highlight the dire nutritional consequences for the development of children during this financial crisis. Furthermore, Lin (2006) indicates that neonatal and postneonatal mortality rates and unemployment rates in Taiwan are strongly correlated, emphasizing that children are the most vulnerable in times of economic crisis. In this sense, Bhalotra (2010) shows that the income shocks at the state level in India caused a substantial increase in infant mortality in rural households.

As regards African countries, here is where the highest rates of child mortality are concentrated, although the existing literature focuses more on explaining the main factors that lead to such high rates -such as high levels of malnutrition or droughts- than in studying the impact of economic oscillations in the progress of infant deaths. In this context, the study by Alderman et al. (2005) on Ethiopia states that measures such as food aid can significantly mitigate the negative effects of certain disturbances on children.

Secondly, other papers simultaneously consider a number of developing countries (Fernández and López-Calva 2010; Schady and Smitz 2010; Anderson, et al. 2011; Renton, et al. 2012, Pérez-Moreno, et al. 2016).

For a set of 5 middle-income countries in Latin America (Argentina, Brazil, Jamaica, Mexico and Peru), Fernández and López-Calva (2010) show that economic recessions have a negative impact on child mortality and also underline an evident relation between economic recessions and the rise of child poverty.

In this respect, and through a descriptive analysis, Anderson et al. (2011) argue that in 19 countries in Asia, macroeconomic shocks negatively affect the poor population, and within it, the most vulnerable groups, such as children.

Likewise, Renton et al. (2012) in a study of 102 low to middle-income countries, point out that economic growth can be fundamental for the improvement of health in the developing world.

More recently, Pérez-Moreno et al. (2016) provide empirical evidence of uneven effects of variations in Gross Domestic Product (GDP) per capita on the evolution of child mortality rate in periods of economic recession and expansion in the Least Developed Countries (LDCS) during the period 1990-2010.

Given this scenario, it seems obvious that the control of the adverse effects of cyclical economic fluctuations are key in improving the living conditions of children and, in particular, in the struggle for child survival.

\subsection{Analytical Framework}

A prominent part of this study, and which today may be of great interest when examining the scope of the effects of the financial and economic crisis of 2007-08 on children, is the framework of analysis proposed by the authors to explain the Interrelationships Between Social and Economic Conditions and the Situation of Childhood (Cornia et al., 1987, pp. 41-55), which identifies the underlying causes that affect the well-being of children during periods of eco- 
nomic recession. These causes are numerous and are often related, although they can be presented in three groups representative of the different sources of childhood well-being. They are the following:

a) Real resources in cash or in kind at the family level. There are three influential variables in the level of resources: subsistence production, monetary income (salary, self-employment or transfers) and the inflation index, especially the one related to food. These resources contribute to the satisfaction of the needs of food, housing, clothing, transportation and to a certain extent, health, water and sanitation, education and childcare.

b) Public expenditure on health, education, childcare, water and environmental sanitation, supplementary food and food subsidies.

c) Family and community characteristics. This section highlights the age, health and education (usually measured by the educational level) of the parents and, in particular, of the mother, as elements that have a marked influence on the generation of childhood well-being within the family.

These three groups of variables are modified to a certain extent during periods of recession, although to different degrees: (1) monetary income, government expenditures, food prices, mothers' age, health and time available for domestic life vary quite rapidly with the changes of economic aggregates; (2) subsistence production, on the other hand, is influenced to a greater extent by structural variables such as the quality and concentration of land, access to means of production and climatic factors; (3) the level of education of mothers is not generally affected by the economic crisis if the latter is short, but will be negative if the crisis lasts for years, especially in those cases in which the level of education is minimal; and (4) especially noteworthy is the change experienced in mothers' health and the time dedicated to their children during periods of economic recession.

\subsection{Main Channels of Influence}

In order to examine how these factors affect the well-being of children, it should be stressed, first of all, that a fall in GDP leads to a decrease in real average income and a notable increase in unemployment. It is difficult to generalize about the changes that take place in relation to the distribution of income: while on one hand, the poor living in low-monetarized subsistence economies may not be excessively affected by the general decline of the economy, on the other hand it is clear that the poor population in the monetarized sector suffers disproportionately from the situation of economic deterioration.

Obviously, the availability of food is also strongly influenced by prices. In developing countries, the demand for food produces a high volatility of prices, especially in the sector of the population with fewest resources, so that an increase in prices produces important reductions in the demand of the poorest, 
who spend a greater proportion of their income on food (normally more than half of their total income, according to FAO, 2011) ${ }^{1}$.

In addition, the availability of food on a family scale in developing countries is also affected to a large extent by the direct distribution of food by international organizations and non-profit organizations, with this aid generating very positive effects on the state of nutrition and on income transfer. During periods of economic crisis this form of supplementary food aid also tends to be reduced.

As a result of all this (the decrease in income, increases in food prices and reduced food aid), food expenses tend to decrease in figures similar to the real fall in income ${ }^{2}$. Although some families can substitute the most expensive foods for cheaper food and with the same caloric content in order to avoid an excessive impact on the consumption of nutrients, this possibility is normally not available to the poorest, and may cause growth delays and serious risks in childhood health.

However, not only the availability of food influences child malnutrition. There are many medical pathologies that come into play in this field, especially in the population under 5 years of age. It is well known that different forms of infection or, more generally, of pathogenic invasion (e.g. diarrhea) reduce the appetite or cause serious loss of nutrients. Its extension depends to a large extent on the level of environmental pollution, and this is directly related to spending on drinking water supply, sanitation, sewage systems, etc.; and in times of recession these expenses tend to be reduced considerably.

Along the same lines we find the availability of health services, to the extent that in recessionary periods health care services frequently worsen, which can translate into morbidity, malnutrition and even mortality.

Furthermore, the state of nutrition of children in infancy and the under-five mortality rate are also directly related to the state of nutrition and health of the mother. An increase in maternal malnutrition is transmitted to the fetus, which thus suffers from delays in growth, which can in turn, result in an increase in the number of abortions and underweight infants. In fact, the considerable increase in low birth weight infants is a clear sign of the deterioration of maternal life conditions that usually occur during periods of severe deprivation.

Finally, it should be noted that a prolonged economic crisis can have a very negative impact on the educational level of future mothers, since it is the girls who often stop going to school earlier in order to save on family expenses and dedicate themselves to the care of the home and the youngest in the absence of mothers who work outside the home to supplement the common income.

\footnotetext{
1 Between 2005 and the end of 2008, wheat and corn prices tripled, and rice prices multiplied fivefold, causing riots in more than 20 countries and plunging 75 million more people into poverty. The most recent data available on domestic prices indicate that grain prices in developing countries have declined significantly from the peaks reached in 2008, although the price of wheat has subsequently risen sharply (FAO, 2011).

2 In the same way as with food, this can also occur with other goods that are fundamental for health, such as medicines or water.
} 
In short, the above statements indicate that the channels through which economic setbacks affect children are numerous, varied and complex. In schematic terms, taking into account some empirical relationships analyzed and referenced in Cornia et al. (1987, pp. 48-55), we can underline the following relations of influence that explain some direct effects of economic recessions on children:
a) Family income $\rightarrow$ Food availability $\rightarrow$ Nutrient intake $\rightarrow$ Nutritional status $\rightarrow$ Morbidity $\rightarrow$ Child Mortality
b) Food prices $\rightarrow$ Food availability $\rightarrow$ Nutrient intake $\rightarrow$ Nutritional status $\rightarrow$ Morbidity $\rightarrow$ Child Mortality
c) Food aid $\rightarrow$ Food availability $\rightarrow$ Nutrient intake $\rightarrow$ Nutritional status $\rightarrow$ Morbidity $\rightarrow$ Child Mortality
d) Health services $\rightarrow$ Health care $\rightarrow$ Morbidity $\rightarrow$ Child Mortality

\section{The Impact of the "Great Recession” on Childhood in Developing Countries}

Although the major impacts of the crisis in macroeconomic terms are concentrated in high-income countries, there is no doubt that the economies of the South, to a greater or lesser extent, have also been affected by the economic deterioration experienced in recent years. And this, obviously, has an impact on the welfare of society, particularly the most vulnerable groups, such as children.

In this context, both multilateral agencies and private investigators have provided arguments and estimates of the possible effects of the last economic crisis on children in developing countries. In this respect, half of the deaths of children under 5 can be attributed to malnutrition (UNICEF, 2016). This is undoubtedly a very negative estimate, though whether it becomes a reality will depend, in any case, on the success of the political responses of multilateral organizations and States, and on how the economic deterioration in particular affects the countries with the lowest rates of development on the planet.

Following Harper et al. (2009), and taking into account experiences from previous economic crises, we can easily understand how last global economic deterioration has been able to affect the most disadvantaged children (see Figure 2). The reduction of remittances from migrants and of Official Development Aid, declining international trade and the falling prices of certain raw materials exported by developing countries, or the difficulty in accessing international financial markets at reasonable prices are key, objectively-verifiable elements that are taking place as a consequence of the last global economic situation. In developing countries, all of the above have repercussions on access to credit for families and enterprises, rising unemployment, underemployment and worsening working conditions, budget cuts in essential public services (education, health, nutrition, housing, water and sanitation, social protection, etc.), or increased social instability and violence and the reduction of social capital, thus significantly affecting social cohesion. In this way, households, 
which play key roles in the well-being and development of children, end up suffering clearly from the impact of the crisis, and particularly children, on account of their high vulnerability, experience negative effects on their essential rights related to survival, development, protection and participation.

FIGURE 2: IMPACT OF THE GLOBAL ECONOMIC CRISIS ON INFANCY

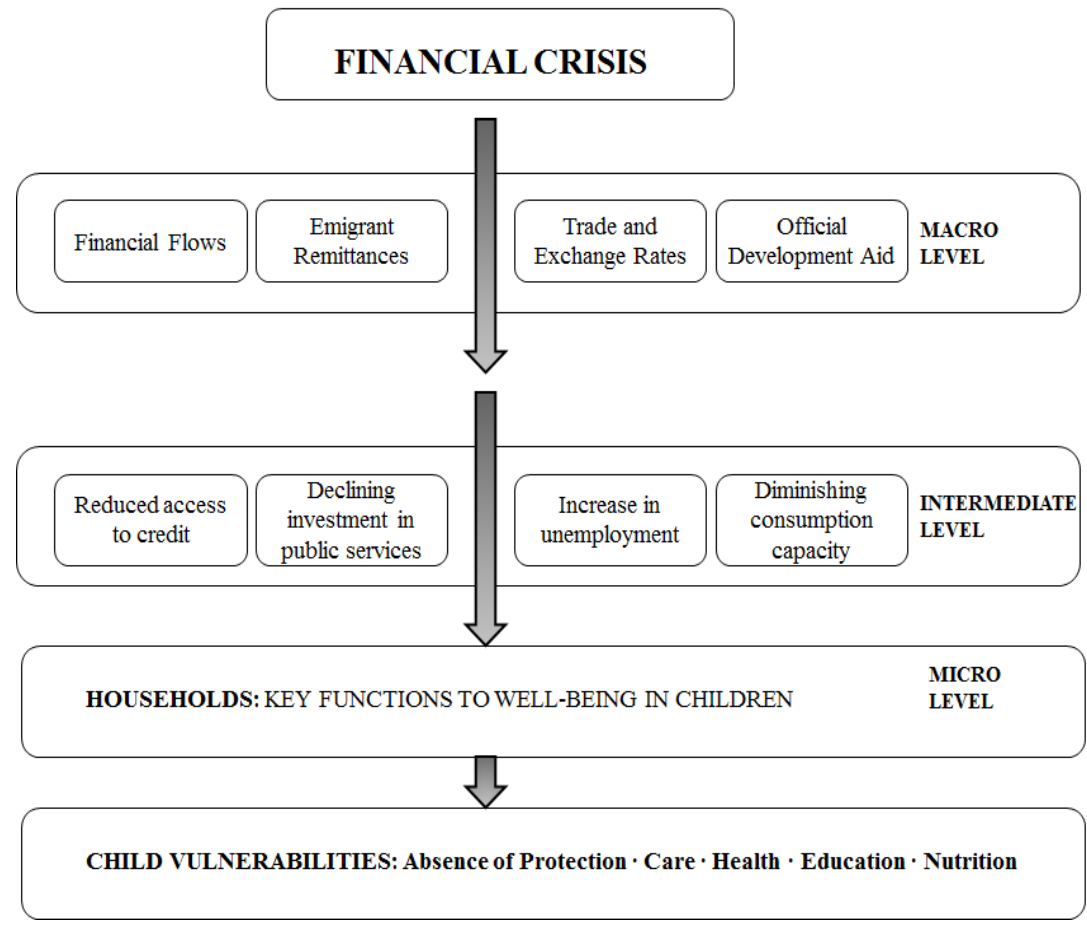

Source: Prepared by the author based on Harper et al. (2009).

Despite its temporary nature, the effects of this crisis on children in developing countries may persist over time, with consequences that may even be irreversible in some cases, caused, e.g., by malnutrition or school drop out due to work obligations.

From the perspective of society as a whole, it could also lead to higher poverty rates for the future, with a consequent reduction in the productive capacity of the economy. Furthermore, and with future generations in mind, it could favor the inter-generational transmission of poverty, thus contributing to the perpetuation of the vicious cycles that characterize underdevelopment.

On the other hand, if we take into account that care for dependents, such as children, is fundamental for human well-being and social development, 
according to Espey et al. (2010), the economic crisis experienced in recent years is highlighting the effects of inadequate attention on education, development, health and child protection. And these problems cannot simply be viewed as problems of paternal neglect but must be considered as common problems of a society in need of policies that give more attention to child care and are integrated within systems of national welfare. In addition, for the future, compromising the level or quality of care a child receives can have a significant impact on long-term development and economic productivity, thus making the improvement of social protection systems a fundamental concern.

Moreover, and in reference to the economic crisis experienced in recent years, Christian (2010) shows that this is associated with poorer dietary quality due to the increase in the price of food, and this leads to an increase in morbidity and the mortality of children in the developing world.

In general, policies on childhood are key to setting children on the paths of healthy living and to teaching them how to make the most of their opportunities in life. Agüero and Valdivia (2009) argue that countercyclical policies should focus on special protection networks for very young children, which would reduce the impact of the recession on child malnutrition and child mortality. In addition, they must be accompanied by a sustained effort to increase the education of girls, so that in the medium term, they provide security for future generations, since heterogeneous effects have been observed resulting from the education of the mother, at least in the case of mortality rates, to the extent that children born to mothers with lower educational levels are more vulnerable.

Finally, it should be stressed that there are sufficient reasons to maintain, during recessionary periods, the levels of social expenditure on children and young people, particularly in the case of children with fewer resources. Richardson (2010) justifies this in particular for three reasons: first, children do not choose the families or societies in which they are born, so it is fair to support those who are disadvantaged by causes beyond their control; second, the way children are cared for today will affect future economies and societies; and third, if vulnerable children lose state support during critical life-cycle periods there will be longterm costs and harmful consequences for them and their families.

\section{FinAL REMARKS}

Despite the considerable progress achieved in children's rights in the last two decades stemming from the Convention on the Rights of the Child, it is clear that challenges remain. The latest reports on the State of the World's Children affirm that, despite significant progress, millions of children still lack the essential services to ensure their survival and reduce their vulnerability to disease and malnutrition. According to Brikci and Holder (2011), real challenges remain: lack of international and national resources, lack of health systems strengthening, lack of human resources at all levels of the health system, limited social protection mechanisms and socio-political factors. 
If we add to this reality the predictable effects of the so-called "Great Recession", there is no doubt that the situation gives cause for serious concern. The decline in ODA from the countries of the North are only a few aspects that help us understand how, once again in history, the impoverished world and in particular, the most vulnerable and underprivileged social strata of these countries, may end up in large part footing the bill for the excesses, incompetence, greed and rapaciousness of the opulent world. For example, with regard to the LDCs of the international community, Cuenca and Rodriguez (2010) point out to LDCs in Asia that international cooperation is inadequate and insufficient to reach the MDGs, and should be accompanied by a greater opening up to commercial exchange. In this context, Pérez-Moreno et al. (2016) find that ODA seems to play a crucial role in counteracting the increase in child mortality rates in recessionary periods, at least in those LDCs receiving greater aid. Therefore, if we are not aware of this and do not react decisively and globally, it is highly probable that the crisis will move us slightly further away from the goals set for 2015 in the MDGs, by slowing down the reduction of extreme poverty and hunger, increasing the lack of schooling for millions of children, child mortality, or health problems related to motherhood, even endangering, in some countries, the significant progress made in the last decades in the field of children's rights.

It is therefore appropriate to draw attention to the importance of strengthening policies to reduce poverty and advance the survival of children beyond the proposed SDGs, by involving both international organizations and States, in both the public and private sectors; but also the non-profit sector, given the difficulties of the previous two sectors in facing the changing economic climate. In line with Oya (2011) the New Poverty and the MDG agendas have been relatively successful in garnering support to increase international assistance for basic needs in African countries but are much less impressive in terms of achieved outcomes and their contribution to development strategies.

Given this scenario, it seems reasonable to consider the need to undertake a real global reaction - preferably coordinated by a UN-linked body in order to avoid the foreseeable devastating effects on the most vulnerable sectors of the population -children in particular- in developing countries.

In political terms, one of the greatest challenges of our society is to ensure that the vulnerability of children is present in political agendas, with the rights of the child taken as a reference. In this sense, the new 2030 Universal Agenda for Sustainable Development, containing 17 SDGs, represents an agenda for all the world's children and provides an opportunity to apply lessons learned through the MDGs and reach the most vulnerable children, both in the countries of the North and the South, establishing responsibilities and goals for all governments and reinforcing a universal approach to human rights that transcends the traditional division between national and international policies. Thus, henceforth and with the goal set on 2030, within the framework of the MDGs, one of the main challenges we face is to combat child mortality and reduce the high rates of poverty that plague children by means of appropriate measures to advance child survival and well-being. 
We must not forget, nonetheless, the importance of investing in children both from an ethical and legal perspective -in the light of the Convention on the Rights of the Child and other international agreements on Human Rightsand for economic, political and social reasons as a key element in breaking the cycle of the inter-generational transmission of poverty, in addition to improving health and well-being. These investments, according to Sen (1999), increase productivity, improve democracy and reduce or prevent other economic and social problems, such as juvenile delinquency, teenage motherhood or domestic violence.

\section{REFERENCES}

Agüero, J.M. and Valdivia, M. (2009): “The Permanent Effects of Recessions on Child Health: Evidence from Peru”, Estudios Económicos, 25(1): 247-274.

Anderson, I., Axelson, H. and Tan, B-K. (2011): "The Other Crisis: The Economics and Financing of Maternal, Newborn and Child Health in Asia", Health Policy and Planning, 26(4), 288-297.

Bhalotra, S. (2010): "Fatal Fluctuations? Cyclicality in Infant in India”, Journal of Development Economics, 93(1), 7-19.

Block, S.A., Kiess, L., Webb, P., Kosen, S., Moench-Pfanner, R., Bloem,M.W. and Timmer, C.P. (2004): "Macro Shocks and Micro Outcomes: Child Nutrition During Indonesia's Crisis”, Economics and Human Biology, 2(1), 21-44.

Brikci, N. and Holder A. (2011): "MDG4 - Hope or Despair for Africa?", Revista de Economía Mundial, 27, 71-94.

Christian, P. (2010): "Impact of the Economic Crisis and Increase in Food Prices on Child Mortality: Exploring Nutritional Pathways", Journal of Nutrition, 140(1), 177-181.

Cornia, G. A., Jolly, R. and Stewart, F. (1987): Ajuste con rostro humano. protección de los grupos vulnerables y promoción del crecimiento, UNICEF, Madrid.

Costa, M.C.N., Andrade Mota, E.L., Paim, J.S. and Vieira da Silva, L.M. (2003): "Infant Mortality in Brazil During Recent Periods of Economic Crisis", Revista de Saúde Pública, 37(6), 699-706.

Cuenca, E, and Rodríguez, J.A. (2010): "Measurement of Disparities between Indicators Associated with the Welfare in Least Developed Countries (LDCs) of Asia", Revista de Economía Mundial, 25, 83-108.

Cutler, D., Knaul, F., Lozano, R., Mendez, O. and Zurita, B. (2002): "Financial Crisis, Health Outcomes and Ageing: Mexico in the 1980s and 1990s", Journal of Public Economics, 84(2), 279-303.

Elson, D. (2010): "Gender and the Global Economic Crisis in Developing Countries: A Framework for Analysis”, Gender \& Development, 18(2), 201-212.

Espey, J., Harper, C. and Jones N. (2010): "Crisis, Care and Childhood: The Impact of Economic Crisis on Care Work in Poor Households in the Developing World", Gender \& Development, 18(2), 291-307. 
FAO (2011): El estado mundial de la agricultura y la alimentación 2011, FAO, Roma.

Fernández, A. and López-Calva, L.F. (2010): “Transitory Shocks, Permanent Effects: Impact of the Economic Crisis on the Well-Being of Households in Latin America and the Caribbean", Estudios Económicos, 25(1), 3-35.

Ferreira, F.H.G., and Schady, N. (2009): "Aggregate Economic Shocks, Child Schooling, and Child Health", World Bank Research Observer 24, issue 2 , 147-181.

Harper, C., Jones, N., McKay, A. and Espey, J. (2009): Children in Times of Economic Crisis: Past Lessons, Future Policies, ODI, London.

International Monetary Fund (2009): Global Economic Crisis: Economic Crisis Starts to Hit World's Poorest Countries, IMF, Washington D.C.

Jolly, R. and Cornia, G.A. (1984): Efectos de la Recesión Mundial sobre la Infancia, UNICEF, Madrid.

Lin, S-J. (2006): "The Effects of Economic Instability on Infant, Neonatal and Postneonatal Mortality Rates: Evidence from Taiwan”, Social Science \& Medicine, 62(9), 2137-2150.

Miller, G. and Urdinola, P. (2010): "Cyclicality, Mortality, and the Values of Time: The Case of Coffee Price Fluctuations and Child Survival in Colombia", Journal of Political Economy, 118(1), 113-155.

Oya, C. (2011): "Africa and the Millennium Development Goals (MDGs): What's Right, What's Wrong and What's Missing”, Revista de Economía Mundial, 27, $1-15$.

Paxson, C, and Schady, N. (2010): "Does Money Matter? The Effects of Cash Transfers on Child Development in Rural Ecuador", Economic Development and Cultural Change, 59(1), 187-229.

Pérez Moreno, S., Blanco-Arana, C. y Bărcena Martīn, E. (2016): “Economic Cycles and Child Mortality: A Cross-National Study of the Least Developed Countries", Economics and Human Biology, 22, 14-23.

Renton, A. Wall, M. and Lintott, J. (2012): "Economic Growth and Decline in Mortality in Developing Countries: An analysis of the World Bank Development Datasets", Public Health, 126(7), 551-560.

Richardson, D. (2010): "Child and Family Policies in a Time of Economic Crisis", Children \& Society, 24(6), 495-508.

Rukumnuaykit, P. (2003): Crises and Child Health Outcomes: The Impacts of Economic and Drought/Smoke Crises on Infant Mortality in Indonesia, (Unpublished manuscript), Michigan State University, Michigan.

Schady, N, and Smitz, M.F. (2010): "Aggregate Economic Shocks and Infant Mortality. New Evidence for Middle-Income Countries”, Economic Letters, 108(2), 145-148.

Sen, A. K. (1999): Breaking the Poverty Cycle Investing in Early Childhood, Inter-American Development Bank, Washington.

UNICEF (2016): The State of the World's Children: A Fair Chance for Every Child, UNICEF, Nueva York. 
United Nations (1989): Convention on the Rights of the Child. G.A. Res. 44/25, U.N., (November 20, 1989).

United Nations Inter-Agency Group for Child Mortality Estimation (2018): Levels and Trends in Child Mortality, UNICEF, New York.

Yamano, T., Alderman, H. and Christiansen, L. (2005): "Child Growth, Shocks, and Food Aid in Rural Ethiopia", American Journal of Agricultural Economics, 87(2), 273-88. 
